\title{
Development of Mobile Learning as a Student Career Planning Media at Senior High School 1 Talang Ubi
}

\author{
Nia Veronica ${ }^{1}$, Edi Purwanta ${ }^{2}$, Muhammad Mahardhika ${ }^{3}$, \\ ${ }^{1}$ Postgraduate Guidance and Counseling, Yogyakarta State University, Indonesia \\ ${ }^{2}$ Postgraduate Guidance and Counseling, Yogyakarta State University, Indonesia \\ ${ }^{3}$ Postgraduate Guidance and Counseling, Yogyakarta State University, Indonesia \\ Corresponding author: niaveronica66@gmail.com
}

\section{A R T I C L E I N F O}

\section{Article history:}

Received may 2021

Revised june 2021

Accepted july 2021

Keywords:

career planning,

mobile learning

\section{A B S T R A C T}

\begin{abstract}
Background of this research is the lack of students' understanding of career planning, there are several career problems faced by students. This study aims to produce a mobile learning-based career planning application at Senior High School 1 Talang Ubi. This development research refers to the steps of research and development (R\&D) by Borg and Gall. Subjects in the initial field trial 6 students scored 79.46 in the very good category, the main field trial 12 students scored 84.07 in the very good category, and the operational field trial 32 students scored 94.47 in the very good category. good. Subject selection was based on the purposive sampling technique. The results showed that (1) the media produced was in the form of a career planning application using Adobe AIR for Android Version 0.1, (2) the mobile learning produced according to experts was suitable for use as a medium for student career planning at Senior High School 1 Talang Ubi.
\end{abstract}

(C) IJAGC 2021, All right reserved ISSN: 2722-2365 (Online) 2722-2357 (Print)

\section{Introduction}

The High school students are teenagers who have an age range of 15-18 years, high school students have several developmental tasks to be achieved. Havighurst said that one of the developmental tasks that must be achieved is choosing and preparing for a career or job (Yusuf: 2006). Adolescence is a time for individuals to start making career plans by looking for various career information of interest to make career decisions (Bardick, Bernes, Magnusson, \& Witko, 2006). Career development in high school students enters the planning stage, which is cognitive by reviewing themselves and their life situations. This is very important for students to make it easier for them to determine the direction of study to be taken. If students do not plan their careers well, it will have an impact on their future career choices.

Career planning is very beneficial for students because it can minimize the occurrence of errors in choosing the available alternatives. Corey stated that career planning is a process 
that includes exploring options and preparing oneself for a career (Sitompul, 2018: 318). Career preparation is required early as possible with the aim that the student has a picture of a future career (Tas'adi\&Sisrazeni, 2017). Therefore, students must be provided with career information so that they can plan a career according to their talents and interests. Teacher guidance and counseling have a very important role also in providing information services to students.

The provision of career guidance information services provided to students must be comprehensive. Guidance and counseling teachers play an important role in helping students achieve optimal developmental tasks, especially in career development. As stated by Gati I., Levin N., Landman-Tal S. (2019: 115) that career guidance aims to help counselees make better career decisions. The importance of career guidance is given to students with the aim that students get accurate and precise information about careers. In adolescence, they experience and face a transition point when they have to make a certain choice regarding their career. Therefore, guidance and counseling teachers must be more creative in making media so that students are interested in doing guidance. Media in guidance and counseling services is needed to increase efficiency and effectiveness in achieving service goals.

Based on interviews with guidance and counseling teachers at Senior High School 1 Talang Ubi, information was obtained that the provision of counseling guidance services was still not optimal, this was due to time constraints in providing services. Guidance and counseling teachers have duties and responsibilities in carrying out guidance and counseling services to students. The task of the guidance and counseling teacher is related to selfdevelopment according to the needs, potentials, talents, and interests of students. There are several duties of guidance and counseling teachers in helping students including career development.

Career guidance and counseling services in schools serve to help students solve career problems and help students prepare for future career plans so that they can be well planned. The implementation of career information services at Senior High School 1 Talang Ubi is still limited and only uses guidance boards and leaflets, this is because counseling guidance teachers do not have class hours to provide classical services to students. This is following the results of research conducted by Veronica, Purwanta, and Astuti (2020: 910) who conducted interviews with $15 \mathrm{BK}$ teachers throughout the city of Yogyakarta, the results of the interviews were that guidance and counseling teachers had limited time in providing services to students. by way of guidance and counseling teachers requires creative and innovative media following the changing times.

The use of innovative career guidance media can increase students' potential and will change the style of applying conventional guidance and counseling. The purpose of technology is to make it easier to access information. Arsyad (2015: 11) says that good media is a media that involves many senses because the more senses are involved, the more likely it is for students to be able to understand and understand the subject matter or in this context guidance material. Based on this, the researchers are interested in developing a media career guidance that aims to be able to help students plan a career in the future, as well as minimize the occurrence of major when proceeding to higher education. 


\section{Method}

The research approach uses the type of Research and Development (R\&D) research. The research model developed by Borg and Gall (Syaodih, 2009: 168), said that in the implementation of development research strategy are ten steps, will but because of time constraints researchers only perform up to seven stages, namely the revision of operational products. The population of this study was all students in class $\mathrm{X}$ at Senior High School 1 Talang Ubi Pali. In this study, the subjects of this initial field trial were 6 students of class X, a small-scale main field test of 12 students of class $X$, operational field trials totaling 32 students of class X. Instrument collection of data that is used in the research is the type of qualitative and quantitative research data. Qualitative data were obtained from expert validation tests on initial field tests by experts, product trials by small groups, and usage trials by large groups in the form of responses, suggestions, and criticisms for product revision materials developed.

\section{Findings and Discussion}

Findings

This study aims to develop a product in the form of career guidance media. The first stage in this research, namely the data collection instrument used in the study is the type of qualitative and quantitative research data. Qualitative data were obtained from expert validation tests on initial field tests by experts, product trials by small groups, and usage trials by large groups in the form of responses, suggestions, and criticisms for the revised product materials developed. collecting data information, namely analyzing the problems that exist in students related to career planning, at this stage researchers distribute questionnaires to students and conduct interviews with guidance and counseling teachers at Senior High School 1 Talang Ubi. Furthermore, the second is a literature study, namely by reviewing several materials related to careers, especially career planning. Furthermore, formulating the problem, based on preliminary research and needs analysis conducted by researchers to students and guidance and counseling teachers at Senior High School 1 Talang Ubi, then formulated the problem, namely providing media for high school students containing career information at Senior High School 1 Talang Ubi as an effort to improve student career planning.

Then the second stage is planning, the initial planning carried out by the researcher is making basic competencies that are in line with the indicators to be achieved, compiling the material according to the content of the material to be presented, namely about the type of work, then making a flowchart and storyboard.

The third stage is the development of the initial product, the initial product development carried out by the researcher is compiling the material that will be included in mobile learning. The steps taken by the researchers are; make competency standards and indicators, assessments, careers, arrangements, applications, developer data, evaluations, and references.

The fourth stage is the trial court early form of assessment and evaluation on mobile learning as a medium for students to do career planning assessment of the media and material. The results of the assessment and evaluation of mobile learning as a career planning medium were carried out by media experts, namely Prof. Herman DwiSurjono, Ph.D. He is one 
of the lecturers of Engineering and Informatics Education, Faculty of Engineering, Yogyakarta State University who has competence in the field of e-learning, overall from the media aspect he gets a score of 75 which is included in the good category. Then the material expert test, namely Mr. Dr. Agus Basuki, M.Pd. He is one of the lecturers of guidance and counseling at Yogyakarta State University, in the field of career guidance, in this material expert test he got a score of 90 .

The initial field trial of mobile learning products as a medium for career planning for high school students was carried out on 6 students who were randomly selected from the media aspect, getting a score of 79.46 which was included in the very good category. Then, the main product test field trials of mobile learning as a media career planning for high school students was conducted on 12 students who get results in a value of 84.07 in the category very well. And operational field trials were conducted on 32 students and got a score of 94.47 which is included in the very good category. The following is an application developed by the researcher:
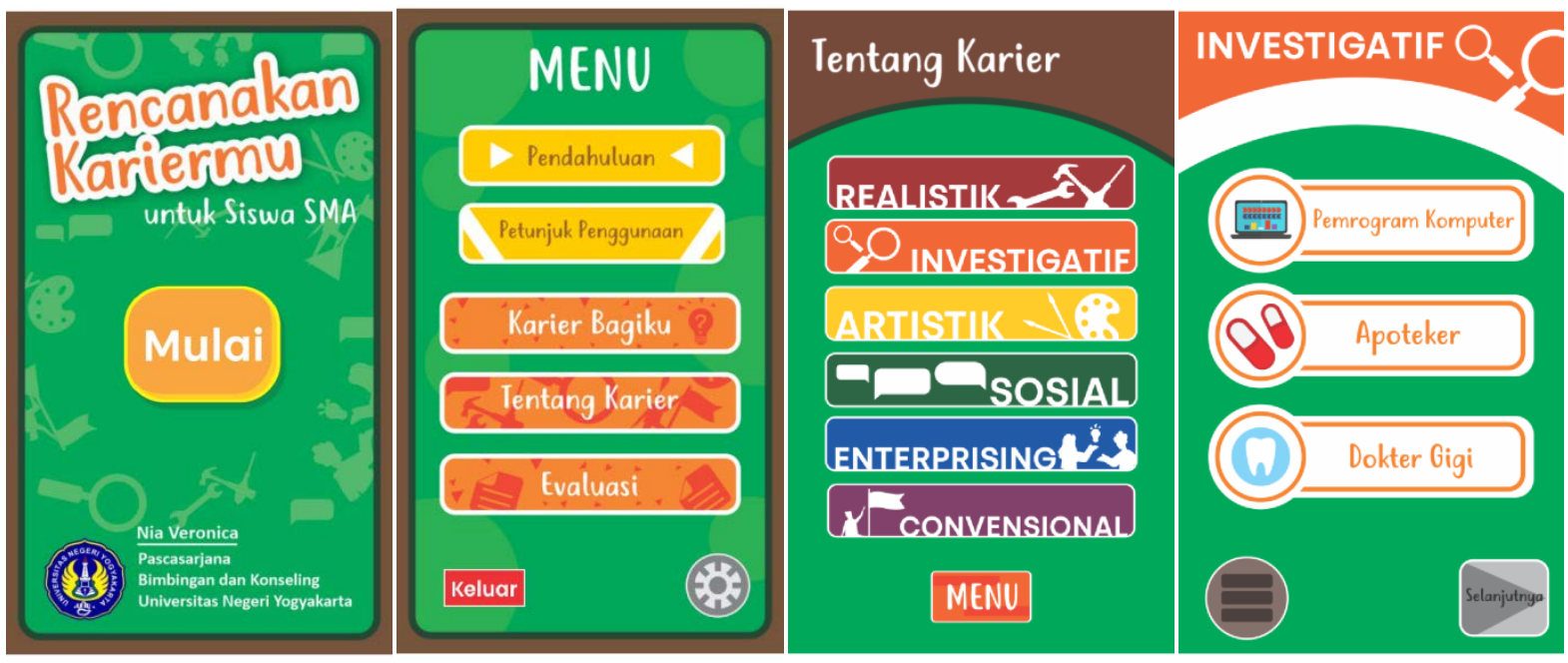

\section{Figure 1.}

\section{Career Planning Application}

Discussion

High school students are required to be able to determine career choices independently, order to determine career choices independently. P Planning for a career is one of the bases in determining career choice. This agrees with Veronica, Purwanta\& Astuti (2020: 908) who said that to avoid failure in career achievement, careful career planning is needed.

Career planning at Senior High School 1 Talang Ubi is still immature, this is evidenced from the results of interviews with class X students who said that they were still confused about further studies. In addition, the guidance and counseling teacher at Senior High School 1 Talang Ubi also provided information that the provision of counseling guidance services was still not optimal, this was due to time constraints in providing career guidance services. Remember the beginning of 2020 the world experienced a major disaster, namely the Covid-19 pandemic which is an infectious disease caused by acute respiratory syndrome coronavirus 2 (severe acute respiratory syndrome coronavirus) that requires students to learn from home or distance learning. According to Caley, Philp, \& McCracken in I Gusti et al (2020: 14974) prevention of this 
outbreak is done by avoiding direct interaction of infected people with people who are at risk of being exposed to the coronavirus. Therefore, distance learning is expected to break the chain of virus spread.

Korucu\& Alkan (2011: 25) say that the use of mobile technology has a major contribution in educational institutions, including the achievement of distance learning goals. Then, Astuti et al (2020) said that guidance and counseling teachers facilitate the use of media, the aim is to help students understand the material presented more quickly. In addition, Sanjaya (2014: 62) also said that with the use of technology students can learn anytime and anywhere according to their interests and learning styles. Thus, the development of career planning mobile learning products can be a mediator for guidance and counseling teachers in providing career information services.

Information service aims to provide students with knowledge about data and facts in the field of school education, occupations, and the field of personal development social, so that those with learning about their environment are better able to organize and plan their own life, Winkel \&Hastuti (2013: 625). Because it's, researchers developed an application form of mobile learning which contains materials about career information Holland typology developed based on the occupation of networking (O'NET). The material contained in mobile learning can make students interested in learning it. Heinich et al. (1999: 234) say that multimedia can reinforce students, providing opportunities for students to learn independently. Then, the results of this development research are supported by research conducted by Saputro (2020: 131) which suggests that students are more interested in information packaged in digital form such as video, a photo, an application, and can be accessed via their respective smartphones. Furthermore, Tas'adi\&Sisrazeni (2017: 185) the more complete the information provided, the more students understand and have additional useful insights for career preparation in entering the world of work following their wishes. In addition, Munir \& Muis (2017: 1) said that Android-based mobile learning is the right medium for the introduction of existing majors in higher education for class XI students of Senior High School 1 Jatirogo so that career guidance in the form of university introductions can be carried out optimally.

\section{CONCLUSION}

Based on the results of research and development of mobile learning as a medium for student career planning at Senior High School 1 Talang Ubi, it can be concluded as follows:

1. The process of developing mobile learning is carried out in stages according to the steps of Borg and Gall. The resulting product is a mobile learning application (mobile learning ) in which there are career planning materials, namely; type of work, job duties, tools used, technological skills, knowledge, abilities, work activities, detailed work activities, job risks, salaries, and work zones.

2. The media developed according to experts is suitable for use, media experts and material experts say that the development of career planning mobile learning is feasible to be tested and developed as a medium of guidance and counseling for students. The results of the student assessment stated that the development of mobile learning was declared feasible to be used. 


\section{References}

Arsyad, A. (2015). Media Pembelajaran. Jakarta: PT Raja GrafindoPersada.

Astuti, B., Veronica, N., Purwanta, E., Novita, D., \&Risqiyian, L. H. (2020, February). Individual Student Planning Model to Develop Career Readiness in High School. In International Conference on Educational Research and Innovation (ICERI 2019) (pp. 61-64). Atlantis Press.

Bardick, A. D. Bernes, K. B., Magnusson, K. C., \& Witko, K. D. (2006). Junior high school student's plans for the future. Journal of Career Development, 32, 250-271.R. Nicole, "Title of paper with only first word capitalized,"J. Name Stand. Abbrev., in press.

Gati I., Levin N., Landman-Tal S. (2019) Decision-Making Models and Career Guidance. In: Athanasou J., Perera H. (eds) International Handbook of Career Guidance. Springer, Cham. https://doi.org/10.1007/978-3-030-25153-6_6.

Heinich, R., Molenda, M., Russel, J. D., \& Smaldino, S. (1999). Intructional media and technologies for learning. UperSadle River: Prentice Hall.

I Gusti, U., Sumartana, I., Waruwu, D., \&Krismawintari, N. P. D. (2020). Implementation of Social Education Models Early Prevention Indicators COVID-19 Spread. Journal of Enginering and Management, ISSN: 0193-4120 Page No. 14971 - 14979 (July 7, 2020).

Korucu, A. T., \& Alkan, A. (2011). Differences between mobile learning (mobile learning) and e-learning, basic terminology and usage of mobile learning in education. Procedia-Social and Behavioral Sciences, 15, 1925-1930.

Munir, M. (2017). Pengembangan Media Mobile Learning (Mobile learning) PengenalanJurusanPerguruan Tinggi Pada Siswa Kelas XI Sman 1 Jatirogo-tuban. Jurnal BK UNESA, 7(3).

Sanjaya, W. (2014). Media KomunikasiPembelajaran. Jakarta: KencanaPrenada Media Group.

Saputro, B., \&Suwarjo. (2020). Pengembangan Permainan Simulasi Berbasis Aplikasi Untuk Meningkatkan Kematangan Karier Peserta Didik SMA.Tesis, tidak diterbitkan, Universitas Negeri Yogyakarta.

Sitompul, L. (2018). MeningkatkanPemahamanPerencanaan Karir MelaluiLayananBimbingan Karir di SekolahdenganMenggunakan Media Gambar Pada Siswa Kelas IX-1 SMP Negeri 1 GebangTahun 2017-2018. TABULARASA, 15(3), 316-327.

Syaodih N. (2009). Metode Penelitian Pendidikan. PT. RemajaRosdakarya Offset. Bandung.

Tas'adi, R., \&Sisrazeni, S. (2017). Pengembangan Modul LayananInformasi Karier di SMK untukPersiapan Memasuki Dunia Kerja. PROCEEDING IAIN Batusangkar, 1(1), 176-189.

Veronica, N., Purwanta, E., \& Astuti, A.B. (2020). Design And Development Of A Mobile Learning For Career Planning In Senior High School. International Journal of Scientific \& Technology Research, 9, 908-913.

Winkel \&Hastuti, S. (2013). Bimbingandan Konseling di Institusi Pendidikan. Yogyakarta: Media Abadi.

Yusuf Syamsu. (2006). PsikologiPerkembangan Anak dan Remaja. Bandung: Rosda Karya. 